\title{
Consumer Switching Behavior: An Effect of COVID-19 in Jember Regency
}

\author{
Agustin HP* and Saiful Amin \\ High School of Economics Mandala, Jember, East Java, Indonesia \\ *Corresponding author email: agustin.mandala.jember@gmail.com
}

\begin{abstract}
COVID-19 has caused economic disruption which is connected globally. The Covid-19 pandemic caused consumer switching behavior as a result of government policies in handling Covid-19. This research aims to obtain an overview of consumer switching behavior during the Covid-19 Pandemic. This research is a quantitative research using a descriptive statistical approach and the research subjects were 100 respondents in Jember Regency who were affected by Covid-19. The data analysis method used was descriptive percentages. A validity testing was done by using the product moment correlation coefficient with the help of SPSS 20 software. Meanwhile, the reliability testing was done by using a single trial administration approach by the Cronbach alpha coefficient formula. The results show that $74 \%$ of people chose to stay at home during the Covid-19 Pandemic with a level of compliance with government policies reaching $93.5 \%$. The majority of respondents, $46.7 \%$ of the respondents, stated that the amount of expenditure for their consumption needs tended to increase, while the total expenditure of other $34.3 \%$ of respondents remained constant, and the other $18.9 \%$ of respondents stated that their total expenditure tended to decrease. In addition, the majority of respondents or as much as $71.6 \%$ thought that government policies in handling Covid-19 have caused some changes in consumption behavior, especially the consumption pattern that consider the quality of service and cleanliness of shopping places with a percentage of $55.6 \%$ and $25.4 \%$ of respondents respectively.
\end{abstract}

Keywords: Consumer Switching Behavior, Covid-19, Economic Disruption

\section{INTRODUCTION}

The Covid-19 Pandemic is not just a health crisis problem. This pandemic has a lot of effect on the socio-economic conditions of people who are connected globally. Although the impact of this pandemic varies from country to country, this pandemic may increase poverty and economic inequality on a global scale so that in the end the COVID-19 Pandemic will cause a globally connected Economic Disruption. The Government of the Republic of Indonesia has imposed social/physical distancing rules to large-scale social restrictions in dealing with the Covid-19 Pandemic. These rules, of course, have an impact on the socio-economic conditions of the people and also cause changes in people's spending behavior. In this condition, many people experience panic buying and make large purchases. On the other side, people who have economic difficulties choose to reduce the amount of their expenditure adjusting their daily needs until the Covid-19 Pandemic ends.

The policy of closing the area entry access in several regions has further sharpened economic disruption. Consumer switching behavior has decreased due to several basic factors, such as the government's suggestion to stay at home, work from home, and social/physical distancing that causes limited space for the consumer market. It forces people to shop in moderation and online shop. In addition, there is a decrease in consumer income as a result of Covid-19. Some people have to lose their jobs, some have a day off and work below normal working hours. This situation causes consumer behavior to decline because, during this pandemic, many consumers are experiencing economic downturns. When the Covid19 pandemic passes, discussing the relationship between the impact of a virus outbreak and the socioeconomic conditions of the people is important for us to develop together, to obtain solutions and meaningful problems, so that the people can be ready to face unexpected obstacles in the future.

Several researches on the impact of the Covid-19 Pandemic have been conducted by previous researchers. [1] in their research results stated that consumers tend to be more careful in choosing products, paying attention to food producers and food origins. This attitude also has an impact on consumer preferences to use e-money and avoidance of 
banknotes in transactions as an effort to avoid physical contact with sellers. Besides, [2] stated that COVID19 is transforming consumer lives: we have covered a "decade in days" in the adoption of digital. The results of this research also stated that behavior changes are not linear and their stickiness will depend on the satisfaction of the new experiences. [3] in his research results stated that market conditions during a pandemic were greatly influenced by the world situation, from an economic, strategic, political, social, and health point of view. [4] stated that the Covid-19 Pandemic has an impact on consumer behavior. The results of this research also stated that the existence of lockdown and social distancing rules has disrupted consumer habits in making purchases.

The Covid-19 Pandemic has led to a new buying pattern for the public that can be called consumer switching behavior. Bansal in [5] defined consumer switching behavior as a movement made by users from one service provider to another. While Keaveney in [6] defined consumer switching behavior as user's consideration to use services with the same category or to switch from a service provider to another one.

Several researches on consumer switching behavior have been conducted by previous researchers. [7] revealed that consumer switching behavior was mostly influenced by the factors of promotion, brand image, and brand commitment, where brand image was the biggest factor in influencing consumer switching behavior. [8] stated that there was a change in people's shopping behavior into online shopping/stores due to time efficiency factors, varied available model of goods, up to date and cheaper goods compared to prices in conventional stores. Besides, [9] stated that the factors of technology and innovation, demographic changes, brand image, perceptions, behavior, attitudes, loyalty, and advertising have a significant impact on consumer switching behavior. Other research result [10] stated that the introduction of attractive products is an important factor in encouraging consumers to switch to other products. [11] stated that consumption efficiency is an important factor that supports changes in shopping behavior. Meanwhile, price and brand are other supporting factors that cause changes in shopping behavior.

Some of the previous research aimed to determine the factors that influence consumer switching behavior in terms of several aspects of the products. This research specifically aims to obtain an overview of changes in people's spending behavior as a result of the
Covid-19 Pandemic. How do consumers view government policies in handling Covid-19? And Will consumers sustainably change their consumption habits?

\section{RESEARCH METHOD}

This research is a quantitative research using a descriptive statistical approach. The descriptive research method is a problem formulation related to the question of the existence of independent variables, either only on one or more variables [12]. Descriptive research is conducted when the research objectives are involved in increasing the reader's knowledge, understanding, and application-related research. In the implementation of this research, the researchers limited the scope of the research area and time. The research area was limited to Jember Regency and the research time was limited from April to August 2020. The research subjects in this research were people affected by the existing Covid-19 Pandemic in Jember Regency. The number of samples was 170 respondents who were selected using a simple random sampling technique. Data collection was done by using questionnaire and interview. To deepen the discussion of this research results, researchers also used secondary data obtained from various reliable sources, such as the Indonesian Republic's Ministry of Health, the Covid-19 task force, expert opinion, and some information from the mass media. Furthermore, the data in this research were processed using descriptive statistical techniques, namely presenting measures of the central tendency such as mean, median, and mode. In descriptive quantitative research, data processing is carried out based on percentage analysis and trend analysis [13].

The descriptive analysis in this research aims to describe changes in consumer behavior in the midst of the Covid-19 Pandemic as a result of the Indonesian government policy in handling the Covid-19 Pandemic. The method used in this research is a survey method that aims to obtain data related to the phenomena or symptoms of a group or individual. The survey was conducted by providing a list of questions to respondents. Furthermore, the answers to these questions are used as a basis for describing the current phenomenon [14]. Furthermore, a graphical representation of the data from the results of data analysis is presented. Data representation is one important thing that the author can use to present 
complex and large findings. Presentation of data in the form of pie charts and bar charts needs to be used to present the proportions and frequencies obtained from quantitative data analysis.

\section{RESULTS AND DISCUSSION}

During the research period, 195 respondents filled out the questionnaire. After verification, there were only 170 adequate questionnaires. Based on the results of data processing, the characteristics of respondents based on gender, age, education level, and income level can be explained in Table 1 below:

TABLE 1. Characteristics of Respondents

\begin{tabular}{|l|l|}
\hline Gender & Percentage \\
\hline Male & $52.1 \%$ \\
\hline Female & $47.9 \%$ \\
\hline Age & \\
\hline Less than 20 & $1.5 \%$ \\
\hline $20-30$ & $29.6 \%$ \\
\hline $31-40$ & $30.2 \%$ \\
\hline $41-50$ & $24.3 \%$ \\
\hline $51-60$ & $12.4 \%$ \\
\hline More than 60 & $1 \%$ \\
\hline Education Level & \\
\hline High school & $21.3 \%$ \\
\hline Bachelor's degree & $23.7 \%$ \\
\hline Magister's degree & $45.6 \%$ \\
\hline Doctoral degree & $9.5 \%$ \\
\hline Income Level & \\
\hline Less than Rp 1 million & $23.7 \%$ \\
\hline Rp 1 million to Rp 3 million & $20.1 \%$ \\
\hline Rp 3 million to Rp 5 million & $29 \%$ \\
\hline Rp 5 million to Rp 8 million & $16 \%$ \\
\hline More than Rp 8 million & $11.2 \%$ \\
\hline &
\end{tabular}

Based on Table 1 above, it can be seen that $52.1 \%$ of respondents were male. In terms of age, the majority of respondents are 31 to 40 years old. Besides, in terms of education level, the majority of respondents have master's degree education with a percentage of $45.6 \%$. Meanwhile, from the income level factor, the majority of respondents had an income ranging from $\mathrm{Rp} 3$ million to Rp 5 million with a percentage of $29 \%$.

\subsection{Public Perspective Towards Government Policy in Handling Covid-19}

The Indonesian government's policy in handling Covid-19 is quite good. This can be seen from the existence of health protocol regulations that are made nicely by the people. Government regulations in handling Covid-19, such as social/physical distancing to large-scale social restrictions, are obeyed by the people of Jember. This is reflected in the answers of respondents regarding the question "What did you do in the midst of the Covid-19 Pandemic?" The result shows that $75 \%$ of respondents chose to stay at home, and only $11.8 \%$ were active as usual. Meanwhile, the rest argued that during the pandemic they worked from home, worked twice a week, and reduced their activities outside the house.

In the questionnaire, another question about "how do you view government regulations regarding Social/Physical Distancing in the midst of the Covid19 Pandemic?" shows that $93.5 \%$ of respondents considered that government regulations regarding Social/Physical Distancing in the midst of the Covid19 Pandemic must be obeyed by the people, only $2 \%$ of respondents answered that these regulations must not be obeyed. While the rest considered that it depended on the situation, looking at political sociology and other aspects.

The results of this research indicate that during the social distancing / physical distancing period, as many as $46.7 \%$ respondents experience an increase in their expenditure for consumption needs, as many as $34.3 \%$ respondents think that the amount spent during the pandemic tends to remain constant, and the remaining $18.9 \%$ respondents experience a decrease in their expenditure for consumption needs. These results indicate that during the pandemic, people have different spending patterns compared to normal times. People tend to buy materials for consumption needs in large quantities to meet their consumption needs, considering that they have to take care of themselves and limit their interactions with other people to avoid the Covid-19 outbreak. Here are some answers by the respondents:

"We prioritize shopping in bulk to avoid meeting new people frequently"

"I was a little worried when interacting directly with sellers, especially in the market, so I spent a lot of shopping for a few times."

"Was anxious when finished shopping, have the items purchased and never been touched by a sufferer of Covid-19, do you have to wash all the items you take home? So bothering and worrying"

However, some of the respondents stated that their amount of expenditure on consumption needs tends to 
be constant. When confirmed, they assumed that consumption needs has to be fulfilled every day, either because of Covid-19 or not. Here are some of the answers of respondents when being asked more deeply related to fulfillment of their consumption needs:

"Shopping as usual, but still use procedures according to health instructions. For example, using a mask, frequently using a Hand Sanitizer, washing your hands with soap, and put the clothes you are already wearing in the washing machine when you want to enter the house."

"It's normal because every vegetable shop provides a place to wash hands with running water"

\subsection{Customer Switching Behavior Conditions during the Covid-19 Pandemic}

Customer Switching Behavior is a consideration for using service where users use services with the same category while moving or switching from one service provider to another. Keaveney in [6]. During the Covid-19 Pandemic, there were many changes in society's behavior in meeting their daily needs. To find out the factors that drive changes in people's shopping behavior during the pandemic, the researchers asked respondents several questions related to customer switching behavior. The respondents' answers can be explained as follows:

\subsubsection{The impact of government regulations on Social/Physical Distancing on changes in consumption behavior}

Government regulations in handling the Covid-19 Pandemic are a factor in the changing behavior of people's consumption. The existence of large-scale social restrictions causes the public's space to be limited, this has a domino effect on the economic activities of the people and disrupts the pattern of public expenditure that has been formed so far. The questions posed to respondents were related to the impact of government policies on changes in shopping behavior. The majority of respondents or as much as $71.6 \%$ agreed that the pattern of spending behavior to meet consumption needs has changed.

These changes in behavior were caused by public concern about the impact of the Covid-19 Pandemic. People tend to be more careful about shopping. Besides, the changes were also caused by the effort to avoid direct contact with large numbers of people or to avoid crowds. After confirming respondents' answers, the followings were obtained:

\begin{abstract}
"Shoppers prefer places that provide good and clean service. Before shopping, you made a list of the names of the items to be purchased, bring a hand sanitizer, if necessary, bring plastic gloves to hold things to keep them hygienic. Buy goods according to your needs only."

"Always be careful when touching objects that are frequently touched by other buyers such as doors, use a hand sanitizer every time you receive change, keep a distance from other people in the shop, wash your hands if there is a place to wash your hands." "For online shopping (using online driver), it is usually only for heavy meals. Meanwhile, other types of products are bought by myself directly to the location. But first considering the condition whether it really requires leaving the house or not, really needs it or not, and always buy ordinary products at the nearest Indomaret, in order to minimize interaction with many people."
\end{abstract}

\subsubsection{Factors that people take into account} when shopping amidst the Covid-19 Pandemic

In the midst of the Covid-19 Pandemic, the main factors that become public consideration when shopping are comfort, safety, and completeness of shopping facilities. The results of this research indicate that $55.6 \%$ of respondents think that comfort, safety, and completeness of shopping facilities are factors that need to be considered when shopping in the midst of the Covid-19 Pandemic.

During the pandemic, people pay great attention to the level of comfort, safety, and shopping facilities compared to other factors such as place, pricing, quality of service, comparable products, and others. This is done to avoid the potential of contracting Covid-19. Things like service quality and pricing are not the main considerations for people when shopping. After confirming the consideration when shopping in the midst of the Covid-19 Pandemic, the following respondents' answers were obtained:

"I will only buy products that are really needed and buy at places that provide a sense of security from the spread of the Coronavirus."

"We recommend shopping online so that we can maintain our safety and our health as long as Covid-19 Pandemic is still in place, and if we want to shop at the market, we must obey orders that have been put in the rules." 
"Buy only basic necessity products and keep your distance so you are safe from the spread of Covid19."

"For shopping items that are not really needed, it is better to postpone it until things are truly safe."

3.2.3. Factors driving the purchase of necessities amidst the Covid-19 Pandemic

The factor that encourage people to purchase necessities during the Covid-19 Pandemic is the concerns about the impact of Covid-19. Based on the results of the research, $39.6 \%$ of the respondents think that concerns due to Covid-19 is a major factor for people in making purchases amidst the Covid-19 Pandemic. Another factor that becomes the consideration of people is the government/experts advice with a percentage of $17.8 \%$.

In purchasing goods in the midst of the Covid-19 Pandemic, people do not pay much attention to advertising factors, discount prices, and even the seller. During the Covid-19 Pandemic, people tend to buy basic necessities such as rice, eggs, instant noodles, sugar, oil, and items needed to maintain health such as hand sanitizers, masks, and vitamins. After confirming the factors encouraging people to purchase goods in the midst of the Covid-19 Pandemic, the following respondents' answers were obtained:

"Shopping according to nutritional and immune needs. Wherever I shop, physical distancing with other people must be implemented."

"Buy necessities as usual. Do not exaggerate."

"Shop as necessary, as needed, so that it does not increase the price of goods and become scarce in the market."

"Buy basic necessities in bulk so you don't leave the house often."

"With the Coronavirus Pandemic, people are panicking over the basic materials available. So that there are products that initially was not rare, it is now also bought up in the midst of other people's needs."

\section{CONCLUSION}

Government policies in handling the Covid-19 Pandemic have led to changes in people's spending behavior. During the Covid-19 Pandemic, the amount of most people expenditure for consumption needs tends to increase. A total of $46.7 \%$ respondents stated that the total expenditure for their consumption needs tends to increase, total expenditure of $34.3 \%$ of other respondents remains constant, and total expenditure of another $18.9 \%$ of respondents tends to decrease. Besides, the majority of respondents or as much as $71.6 \%$ of respondents think that government policies in handling Covid-19 have caused changes in consumption behavior, especially the consumption pattern that considers the quality of service and cleanliness of shopping places with a percentage of $55.6 \%$ and $25.4 \%$ of respondents respectively. The factors that encourage buying necessities amidst the Covid-19 Pandemic are the concerns about the impact of Covid-19 and the advice of the government or experts. The types of goods purchased during a pandemic are necessities such as rice, eggs, instant noodles, sugar, oil, and items needed to maintain health such as hand sanitizers, masks, and vitamins.

\section{REFERENCES}

[1] W. Widayat and Z. Arifin, "Attitude and Behavior to Eating in the Time of COVID-19; A Case Study of Adolescent Consumer in Indonesia," J. Inov. Ekon., vol. 5, no. 3, pp. 113, 2020.

[2] S. Kohli, V. Fabius, and S. M. Veranen, "How COVID-19 is changing consumer behavior now and forever," McKinsey Anal. Partnersh., 2020.

[3] F. de Andreis, "9 / 11 Effect as Economic Consequence of Pandemic Covid-19," Int. J. Manag. Sci. Bus. Res., vol. 9, no. 3, pp. 217224, 2020.

[4] J. Sheth, "Impact of Covid-19 on consumer behavior: Will the old habits return or die?," $J$. Bus. Res., vol. 117, pp. 280-283, 2020.

[5] I. Permana, "Customer Switching Behavior dalam Membeli Batik dari UKM," Bus. Innov. Entrep. J., vol. 1, no. 1, pp. 48-52, 2019.

[6] A. Gupta, B. C. Su, and Z. Walter, "An empirical study of consumer switching from traditional to electronic channels: A purchasedecision process perspective," Int. J. Electron. Commer., vol. 8, no. 3, pp. 131-161, 2004.

[7] R. R. Kawengian, "Determinants of Consumers Brand Switching Behavior in The Purchase of Mineral Water Products in Manado City," J. EMBA J. Ris. Ekon. Manajemen, Bisnis dan Akunt., vol. 3, no. 2, pp. 54-67, 2015.

[8] S. A. Lisa, Octaviani, "Fenomena Perilaku 
Belanja Online Sabagai Alternatif Pilihan Konsumsi di Kalangan Mahasiswa Universitas Negeri Surabaya," J. Paradig., vol. 7, no. 2, pp. 1-16, 2016.

[9] A. Thapa, "Consumer Switching Behaviour: A Study of Shampoo Brands," Abhinav J. Res. Coomerce Manag., vol. 1, no. 9, pp. 98-106, 2012.

[10] Y. Liu, H. Li, X. Xu, V. Kostakos, and J. Heikkilä, "Modeling consumer switching behavior in social network games by exploring consumer cognitive dissonance and change experience," Ind. Manag. Data Syst., vol. 116, no. 4, pp. 801-820, 2016.

[11] B. Mahadin, "Factors Affecting Customer Switching Behavior towards Hybrid Electrical Vehicles (HEV's) from a Customer Perspective in Jordan," Eur. J. Mark. Econ., vol. 1, no. 3, p. 53, 2018.

[12] Sugiyono, "Statistika untuk penelitian." Alfabeta, Bandung, 2011.

[13] M. Hussain, "Descriptive statistics presenting your results I Descriptive statistics - presenting your results I Qualitative Variable Analysis: Types of Statistical Analyses: Descriptive Statistical Analysis :," J. Pak. Med. Assoc., no. July 2012, 2014.

[14] A. Wahyuning, "Penelitian Survey Deskriptif: Format Penelitian Deskriptif, Jenis Data dan Analisis Data Penelitian Deskriptif," in Fakultas Ilmu Komunikasi, Universitas Mercu Buana, Program Studi Broadcasting, Fakultas Ilmu Komunikasi, 2020, p. 18. 